\title{
Association News
}
381 106th Annual Meeting
383 APSR Editors' report
385 Congressio- nal Fellowship Office Assign- ments
3862010 Minority Fellows
3882009 PS Review- ers Insider

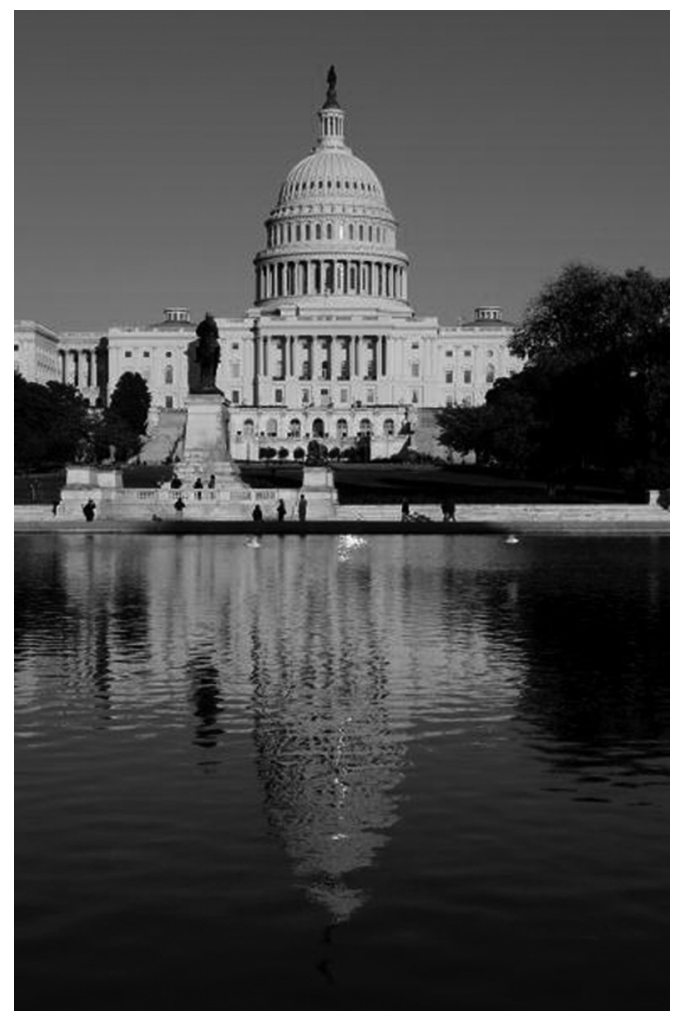

\section{The Politics of Hard Times: Citizens, Nations, and the International Systems under Economic Stress}

\author{
Melissa Pewett, Manager, Meetings and Conferences
}

$\mathrm{F}$ or over one hundred years, APSA's Annual Meeting and Exhibition has provided scholars a unique opportunity to share research, present papers, and network with colleagues. And although each meeting has provided a distinct and worthwhile experience, the 106th Annual Meeting and Exhibition promises to bring one of the most stirring meeting programs yet. Aptly convening in the nation's capital, Washington, DC, more than 7,00o attendees will discuss the latest political science research and theory as it relates to the theme of "hard times" facing the world economy. Program chairs Lisa Martin, University of Wisconsin-Madison, and Andrea Campbell, Massachusetts Institute of Technology, developed a theme that raises questions across many areas of specialization. With more than eight hundred panels organized by 50 thematic divisions,
60 related groups, APSA committees, and presidential task forces, these questions will be explored over the course of the four day event.

The 2010 APSA Annual Meeting and Exhibition will be a rewarding opportunity for political scientists at any stage in their career, featuring valuable professional activities and networking opportunities. Along with panels, roundtables, and posters, the meeting features more than two hundred business meetings and receptions. Participants can also take part in several professional development opportunities, including an exhibition of more than one hundred organizations showcasing their publications, software, and technical tools, and the eJobs Placement Service. All these events will be held in one of three area hotels, the Marriott Wardman Park, the Omni Shoreham Hotel, and the Hilton Washington.
With its variety of professional and scholarly activities, networking events, and vibrant location, the 2010 Annual Meeting and Exhibition is an event not to be missed.

\section{REGISTRATION}

Registration is now open. All presenters must register by April 23 in order to secure their space in the program. Other attendees can register at the preregistration rates until August 6. You can register for the meeting by logging into your MyAPSA account and following the link under the 2010 Annual Meeting header. If you do not have a MyAPSA account, you can set one up for free at www.apsanet.org/member/. Both member and nonmember registration rates are available, though we do encourage nonmembers to join in order to take advantage of the discounted member registration rates and the 
other valuable services offered by the association.

\section{HOUSING}

APSA has negotiated special meeting room rates at the Marriott Wardman Park, the Omni Shoreham, and the Hilton Washington. You can only secure the reduced meeting rate by booking your room through APSA's official housing bureau, Travel Planners. For more information on meeting hotels and to book your room, visit www. apsanet.org/2010 and click the Hotels link.

\section{SPECIAL PROGRAMMING}

In addition to the programmatic highlights listed here, the Preliminary Program will be available online beginning in mid May. The online program will be updated daily until the meeting begins.

\section{Awards Luncheon and Ceremony}

The annual Awards Luncheon and Ceremony honors scholars for their exceptional contributions to the discipline and profession. In addition to the annual career awards, this year, the association will also be presenting the Ithiel de Sola Pool Award, which is presented triennially. The award is presented to a scholar selected to present a lecture exploring the implications of research on issues of politics in a broad range of scholarship pursued by Ithiel de Sola Pool, including political theory, political behavior, political communication, science and technology policy, and international affairs. After the invitationonly luncheon, the ceremony will be open to all APSA Annual Meeting attendees.

\section{Graduate Student Reception}

The Graduate Student Reception is one of the most highly anticipated events of every annual meeting. This networking opportunity is a way for the Association to recognize the future of the profession and provide opportunities for graduate students to connect with peers.

\section{Opening Reception}

On the first evening of the meeting, APSA invites all members to the Opening Reception for an evening of music, hors d'oeuvres, cocktails, and camaraderie.

\section{Presidential Address}

APSA President Henry Brady, University of California, Berkeley, will address the association at a new time and day, Friday at noon.

\section{Reception Honoring Teaching}

Each year, the Association recognizes those who have made a significant impact both in the profession and in the classroom. Campus teaching award winners from across the country will be honored at this special event, which is open to all attendees.

\section{General Membership Meeting}

The general membership meeting is an opportunity to bring association business before the APSA president. Additionally, the general membership meeting is the time when current APSA President Henry Brady will pass the gavel to President-Elect Carole Pateman, University of California, Los Angeles. All members are asked to attend this very important meeting, conveniently rescheduled for Saturday at noon.

\section{VISITING WASHINGTON, DC}

Washington, DC, is a city known for its rich history, cultural diversity, and lively arts community. Visitors to DC can take in national monuments, explore museums, and discover the charms of the city's unique neighborhoods. Washington is the perfect city to explore on foot or with public transportation. And with three international airports nearby, traveling to Washington, DC, is easy. Ronald Reagan Washington National Airport (DCA), Washington Dulles International Airport (IAD), and Baltimore Washington International Airport (BWI) are all within 45 minutes of downtown Washington, DC, and are serviced by both low-cost airlines and business airlines.

\section{Travel Tips}

Public transportation in Washington DC is safe, clean, efficient, and easy to use. Washington's Metrorail system is considered one of the best in the world and services many locations throughout the city. In addition to the rail system, Metrobus provides connections for locations not serviced by Metrorail.

Washington, DC, is a great walking city. It's easy to get around by foot to visit monuments, museums, and restaurants.

Taxis are plentiful in DC, a city with one of the nation's highest taxi per citizen ratios. All taxis in DC are now metered.

\section{Resources}

Washington DC Visitors Bureau Web site: http://washington.org/index.php. 